\title{
Human Freedom and Effective Corporate Income Tax Rates of CEE Listed Companies Marina Purina *
}

\begin{abstract}
:
This paper analyses firm-specific and country-specific factors that have an impact on the effective corporate income tax rates (ETR) for CEE listed companies based on data obtained from the BvD Amadeus database. Business factors analysed in this research are the company size, leverage, capital and inventory intensity, and return on assets. Concerning the country-specific factors, chosen were the statutory corporate income tax rate and cultural factors represented by personal and economic freedoms covered by the Human Freedom Index (HFI), making this study different from others. The tested hypotheses predict significance of all the stated variables. Nine models were analysed based on three ETR denominators (EBT; turnover; cash flow) and three groups of countries (whole sample; sample excluding Russia; sample consisted of Bulgaria, Croatia, Poland, and Romania). Based on the panel data regression analysis and particularly the Feasible Generalised Least Squares estimator, a significant impact on the ETR was found for all variables in all the models. The main variable of interest, the HFI, came always with a negative coefficient demonstrating that, for CEE countries, a higher level of freedom is associated with a lower ETR. Findings for the remaining variables are in line with the existing literature.
\end{abstract}

Key words: Effective corporate tax rate; Firm-specific factors; Country-specific factors; Human Freedom Index.

JEL classification: H25, M41.

\section{Introduction}

The effective tax rate (hereinafter "ETR") has always been a point of interest for economists due to its valuable characteristics. Although the statutory tax rate (hereinafter "STR") remains same for all the taxpayers (or for a specific group of taxpayers in the case of progressive taxation), the individual tax rates vary greatly because of the tax reductions and exemptions, but possibly also due to tax evasion and tax avoidance.

Major attention is devoted to the effective corporate income tax rate as far as it has a great impact on the profitability of companies and their decisions within various

Marina Purina, Faculty of Finance and Accounting, Prague University of Economics and Business, Czech Republic; e-mail: marina.purina@vse.cz; Orcid ID: 0000-0003-2206-8965. I would like to thank doc. Ing. David PROCHÁZKA, Ph.D. for his valuable comments. However, responsibility for any errors in the resulting article remains my own.

The article is processed as one of the outputs of the research project F1/91/2017 funded by the Internal Grant Agency of Prague University of Economics and Business. 
spheres of activity. Much research has been aimed at detecting the factors that affect the ETR: Kubátová and Říhová (2009); Tsakumis et al. (2007); Němec and Dulák (2017), etc. This type of analysis may be applied at both the microeconomic and macroeconomic level, for instance to predict possible changes in the ETR of a particular firm or for the whole country.

A company's ETR is affected by numerous factors, which may be divided into those that are firm-specific and country-specific ${ }^{1}$. Firm-specific factors, such as the company's size, growth, and profitability, demonstrate a high level of dependence on the company's decisions; however, these are still not under its full control. Vice versa, country-specific factors are determined by the macroeconomic and political situation in the state (or in the world).

While economic factors have already been analysed thoroughly (see Literature Review for details), there still exists a gap in studies researching how cultural aspects affect ETRs. Livingston (2020) applies anthropological, sociological, and other social sciences' methodology to demonstrate how different tax systems (especially Western and non-Western) pursue different values. The fact that culture has an influence on tax morale has been proved by numerous pieces of research (e.g. Torgler, 2007; DeBacker et al., 2012, etc.).

This paper aims to analyse the firm-specific and country-specific variables impacting the ETR with an emphasis on the cultural aspects, represented by specific levels of freedom within the given society. Central and Eastern European (CEE) countries were chosen for this purpose, namely, Albania, Bulgaria, Croatia, the Czech Republic, Estonia, Hungary, Latvia, Lithuania, Poland, Romania, Russia, Slovenia, and Slovakia. Considering their national and cultural diversity, it is worth examining whether their communist past has left a mark on their tax morale and, consequently, if there are mutual cultural characteristics affecting the ETR. Evidence in favour of this statement may be found, for example, in Torgler (2007) where the differences between the level of tax morale in West and East Germany were described.

This paper is organised as follows. Section 1 introduces the context of the research, its goal and structure. Section 2 offers an up-to-date literature review to explain the role of the analysis within the existing state of knowledge. Section 3 describes how the data was collected and what prerequisites the model is based on. Section 4 is devoted to the outputs obtained as a result of testing the model; the outcomes are also discussed and compared with existing literature. Section 5 contains conclusions and suggestions for future research.

1 In some studies, these are referred to as the business and institutional factors, respectively (e.g. Fernández-Rodríguez et al., 2020). 


\section{Literature review}

Research in the field of ETR may be divided into microeconomic and macroeconomic streams.

Microeconomic - or firm-specific - studies, starting with the classic model of Allingham and Sandmo (1972), deal with the taxpayer's decisions according to different conditions. It soon became clear that the standard description of a rational taxpayer weighing up the risks and benefits of tax evasion does not suit the reality overly well. Psychological concepts, such as individual preferences and morals, arise here. These may also be applied in the case of corporate taxes because actions are ultimately taken by individuals with their own particular belief systems.

Since then, tax morale - "nonpecuniary motivations for tax compliance" (Luttmer and Singhal, 2014) - has become a popular subject of research. It is often linked to the country (or culture) an individual belongs to. For example, the World Values Survey authors (Inglehart et al., 2014) have asked their respondents to answer whether cheating on taxes was justifiable. In the latest completed 6th wave (2010$2014 ; 60$ countries) the total of $59.8 \%$ of respondents worldwide have opined that it was never justifiable. Data across the regions vary greatly: the highest intolerance to cheating on taxes $(86.0 \%)$ was registered in Turkey while the lowest in Haiti $(20.3 \%)$. Nevertheless, the honesty of the provided answers remains questionable. An individual's motivation to 'look better' by giving the 'expected' answers cannot be overlooked.

Detailed studies on tax morale are available for many countries. For instance, Frey and Torgler (2007) explained the low level of tax morale in the former Soviet countries as conditional cooperation ("I will pay taxes only if I am sure that the others will pay them as well.") and low confidence in the government. Complex research by Torgler (2007) is available for Germany, where tax morale in former East and West Germany has been analysed. There is also evidence in favour of the hypothesis that an individual's culture is more important to the question of tax morale than his or her current residence (DeBacker et al., 2012; Kountouris and Remoundou, 2013).

Tax morale as a characteristic of a large group of people sharing the same values leads neatly to the macroeconomic (or country-specific) level. Within this stream of analysis, the ETR is usually calculated as the amount of taxes to GDP ratio. Nevertheless, the link between the ETR and tax morale asks for further research. Classic studies (Kubátová and Ríhová, 2009; Tsakumis et al., 2007; etc.) take into account only macroeconomic variables such as the size of the economy, population characteristics, the size of the corporate sector, inflation, incorporation measures, statutory tax rate, etc. Tax noncompliance is also widely studied from the legal point 
Purina, M: Human Freedom and Effective Corporate Income Tax Rates of CEE Listed Companies.

of view, concentrating on the government's role, tax amnesties, and possible reforms within this field (e.g. Posner, 2000).

However, there is still little attention paid to the cultural diversity in the ETR studies. There are papers proving that culture and economic freedom positively affect economic growth in general. Understandably, economic freedom plays a more important role here, but culture offers an intrinsic explanation of the total level of freedom in any society. Cultural components such as trust, respect, individual self-determination, and civil obedience establish interactions between individuals, firms, and governments (Williamson and Mathers, 2011).

As already mentioned, the reason for including such a parameter in the analysis is the well-known interdependence of tax morale (and therefore the ETR) and cultural background. Better tax morale leads to more accurate and timely compliance with duty obligations, which may quite possibly result in higher tax payments and the higher ETR at both the micro- and macroeconomic levels. Many researchers have proven this statement in different ways. Torgler and Schneider (2004) found a strong correlation between culture and institutions, which has an impact on tax morale even within a single culture. Cross-cultural differences for individuals and companies are more obvious and have been recorded, for instance, by Cummings et al. (2004), DeBacker et al. (2015), Gulev and Lierse (2011), Kountouris and Remoundou (2013). These studies demonstrate that culture is one of important determinants for the given society's attitude to institutions including government; this has a direct link to tax morale - a willingness to calculate and pay taxes according to the laws enacted by the government.

Recently published research on taxation (Fernández-Rodríguez et al., 2020) considers, amongst other factors affecting the ETR, the country's level of development according to World Bank data, the Index of Economic Freedom (IEF), and institutional quality as measured by Worldwide Governance Indicators (WGI) such as the Rule of Law, Government Effectiveness, and Regulatory Quality.

As of 2020, the IEF has analysed the following areas: Rule of Law (property rights, government integrity, judicial effectiveness); Government Size (government spending, tax burden, fiscal health); Regulatory Efficiency (business freedom, labour freedom, monetary freedom); and Open Markets (trade freedom, investment freedom, financial freedom). (The Heritage Foundation, 2020).

The WGI have been developed by Kaufmann et al. (2011). Three other indicators that were not included in the study by Fernández-Rodríguez et al. (2020) are: Voice and Accountability; Political Stability and Absence of Violence; Control of Corruption.

With respect to economic freedoms, an organisation is not able to function without taking into account its cultural environment. Culture is intrinsic not only to human 
norms and behaviours, but also to those of a business. A company's culture is often the product of the cultural norms (including personal norms) prevalent in the country of its origin. The ETR obviously depends not only on the STR, but also on the management's fiscal decisions, including those on tax planning and possibly also tax avoidance and tax evasion. The personal and economic freedoms that exist within the given society can help better understand to what extent decisions and actions taken regarding taxes are acceptable - both from the point of view of a manager and of the government. For example, in the modern Russian business sphere the term 'tax planning' is mostly used as a full synonym for 'tax avoidance' and it is often interpreted by the authorities as 'tax evasion' resulting in legal procedures (Audit-it, 2017). On the one hand this is the result of the government's power, while on the other hand, society's mutual attitude to taxes is that they are an obligatory payment that is necessary to be reduced at (almost) any cost. Therefore, to broaden the existing state of knowledge, the goal was to find a complex index that is able to cover not only the above-mentioned areas of economic freedom and the quality of government, but also other important cultural characteristics such as personal freedom. The correlation between economic and personal freedom was proven to be at the level of 0.71 for 2018 (Vásquez and McMahon, 2021). The search resulted in choosing the Human Freedom Index (HFI) published by the Cato Institute, the Fraser Institute, and the Liberales Institut at the Friedrich Naumann Foundation for Freedom. To date, this is the most comprehensive overall freedom index covering 162 countries in its most recently published version (2020). The index describes the different legal and cultural characteristics relating to the most important fields of economic, civil, and personal freedom. On a scale of 0 to 10 , where 10 represents most freedom, the average HFI for 2020 was 6.93. New Zealand, Switzerland, and Hong Kong enjoyed the highest HFI whereas Venezuela, Sudan, and Syria took the lowest positions in the ranking.

As for 2020, the HFI consists of two equally weighted sub-indices - personal and economic freedom - and 76 indicators covering the following areas: legal protection and security (rule of law; security and safety); specific personal freedoms (movement; religion; association, assembly, and civil society; expression and information; identity and relationships); and economic freedoms (size of government; legal system and property rights; sound money; freedom to trade internationally; regulation of credit market, labour market, and business) (Vásquez and Porcnik, 2017-2020).

The main limitation of the HFI is its structure and the relative importance of the indicators used in view of the fact that freedom may be defined from different perspectives. However, the opinion is that the wide range of characteristics covered by the HFI enables it to serve as an alternative to the above-mentioned indices and to enhance the model. It is important to mention that the HFI covers all areas that are included in the IEF and adopts the WGI's methodology when calculating 
Purina, M: Human Freedom and Effective Corporate Income Tax Rates of CEE Listed Companies.

the Rule of Law indicator together with covering Government Effectiveness and Regulatory Quality aspects as well. This may account for the high level of correlation between these indices (own rough estimation of the correlation coefficient for years 2016-2020 is 0.746 for HFI and IEF and 0.982 for HFI and WGI).

The HFI may also be viewed as an approximation of Hofstede's dimensions of culture (Hofstede, 2015). Potentially a narrower equivalent may be the result of the World Values Survey (Inglehart et al., 2014). Unfortunately, the specific data is not available for some CEE countries: for instance, the last wave in which the Czech Republic took part was the third (1995-1998), which is not compatible with up-to-date information.

The choice of the CEE region may be explained by the rich cultural and national diversity within this territory, which also shares a mutual command economy experience in the recent past. Most centrally planned European economies organised their tax systems according to the Soviet Union's pattern. Has the communist ideology unified the people's attitude towards taxes or has it remained unique for each culture? Berenson (2018) demonstrated a significant difference in tax arrears (unpaid taxes) in Poland, Russia, and Ukraine in the 1990s-2000s, which smoothed in the 2010s due to, amongst other factors, the adoption of a new, more Western-like, way of interacting with taxpayers. However, most studies on the ETR in this region are traditionally focused on tax competition: CEE countries are known to offer lower tax rates in comparison with other European states together with a wide range of investment incentives (e.g. Sedmihradsky and Klazar, 2002; Podviezko et al., 2019).

There are a few papers analysing aspects of ETR in CEE companies. Recent research on the ETR in the Czech Republic (Němec and Dulák, 2017) found that size of companies, capital and inventory intensity, return on assets, economic activity classification, and legal form were the most significant factors. Purina (2017) compared Czech and Russian 'blue chips' ETRs and demonstrated that, for both countries, internal factors such as assets, equity, and debt ratio had a more significant impact on the ETR than external factors, namely, Paying Taxes index and average oil price (the last two variables were prominent only for Russia). Lazar (2013), examining the ETR in Romania, offered three variants of the ETR calculation taking into account labour-related and non-profit taxes. In his subsequent study (Lazar, 2014), significant effects on the ETR were found for capital intensity, leverage, and profitability.

This paper extends the research by taking into account all CEE countries and including in the analysis cultural aspects represented by levels of economic and personal freedoms and government quality as measured by the HFI. This approach may broaden the results by revealing how interactions between 
different society institutions, which cannot be described in terms of classic economic concepts, affect the ETR. Livingston (2020) highlighted the fact that national cultural differences are important in tax matters even within the globalised world. It would also be worth studying whether the differences between CEE cultures are deep enough to have an influence on the ETRs of the listed companies. According to Frey and Torgler (2007), former Soviet Union countries demonstrated lower tax morale than post-communist CEE countries. This point of view has been developed by Trüdinger and Hildebrandt (2012), who found that community orientations are more significant in post-communist societies, at the cost of rational considerations.

\section{Research Design and Hypotheses}

\subsection{Hypotheses}

Based on existing literature described in the previous section and adopting Fernández-Rodríguez et al. (2020) methodology, the factors to taken into account were divided into two groups: those that are firm-specific and those that are countryspecific. Micro backward-looking methodology was used according to Nicodème (2007) and Lazar (2013). The following firm-specific factors were assumed:

- A company's size measured by its total assets is a traditional variable in this kind of research, while its influence on the ETR may be ambivalent (Fernández-Rodríguez et al., 2020). Larger firms are usually the subject of careful government and society scrutiny, which makes tax-reducing more complicated (political cost theory). However, large companies may also achieve some level of political influence and take advantage of free-riding (political power theory). Offshore tax planning is also more approachable for larger businesses. More details can be found in Becker (1983) and Zimmerman (1983). Here, a sign is not predicted.

- A company's leverage usually reduces the tax burden due to the fact that interest expenses are tax deductible, so the coefficient is predicted to be less than zero. Purina (2017) demonstrated this for the Czech Republic and the Russian Federation. The same effect for Romania was described by Lazar (2014). The debt tax shield leads to a so-called tax-induced bias: debt financing is often preferred to equity instruments (Fatica et al., 2012).

- The structure of a company's assets (i.e. its capital intensity and inventory intensity), may affect the company's ETR in both directions. However, most evidence indicates that capital intensity is associated with a lower ETR because of depreciation, whereas inventory intensity does not provide such a possibility (Fernández-Rodríguez et al., 2020; Sugeng and Badrus, 2020). Lazar (2014) described a negative correlation in both cases. 
Purina, M: Human Freedom and Effective Corporate Income Tax Rates of CEE Listed Companies.

- A company's profitability as measured by return on assets (ROA) is a control variable that has to be related to tax burden. In most cases, the correlation is positive as more profitable firms tend to have higher ETRs (Gupta and Newberry, 1997); however, some studies record a negative correlation for emerging economies, which is most probably in line with the political power theory (Fernández-Rodríguez et al., 2020).

Not only might firm-specific (internal) factors affect a company's ETR. The necessity for including country-specific factors has already been explained. These are named in the following list:

- Economic and personal freedoms are represented by the HFI described above. The coefficient sign is the subject of this study. On the one hand, a higher level of economic freedom is associated with better tax collection and a greater tax burden (Miller and Kim, 2016; Molina-Morales et al., 2011). On the other hand, there are studies where this relation is the opposite for some aspects of institutional quality such as Regulatory Quality and the Rule of Law (Fernández-Rodríguez et al., 2020; Fonseca-Díaz et al., 2014). Including the additional areas covered by the HFI could broaden the existing state of knowledge.

- Statutory tax rates (STR) are included in the analysis as a control variable. In most cases, an increase in STR will be followed by an increase in the ETR, excluding extreme situations where taxpayers consider the tax rate to be unjustifiably high (as Laffer's curve describes). Nevertheless, political power theory needs to be taken into account as listed companies may have reached a certain level of influence enabling them to decrease their taxes in spite of growth in the STR.

Taking all assumptions into consideration, the following hypotheses were formulated:

H1: Firm-specific factors are related to the ETR.

H1.1: A company's size is related to the ETR (expected sign: '?').

H1.2: A company's leverage is related to the ETR (expected sign: '-').

H1.3: A company's capital intensity is related to the ETR (expected sign: '?').

H1.4: A company's inventory intensity is related to the ETR (expected sign: '?').

H1.5: A company's profitability is related to the ETR (expected sign: '+').

$\mathrm{H} 2$ : Country-specific factors are related to the ETR.

H2.1: Economic and personal freedoms are related to the ETR (expected sign: '?').

H2.2: Statutory corporate income tax rate is related to the ETR (expected sign: '+'). 


\subsection{Data description}

The HFI is published with a two-year lag, which means HFI 2020 published in early 2021 contains data from 2018. The earliest available HFI using methodology compliant with contemporary assessments is the HFI 2015. This is the reason why the period chosen for the analysis was specified as 2013-2018.

The data for this period was obtained using the BvD Amadeus database. The search strategy included all active listed companies with recent financial information from CEE countries. A usual condition for this type of research is the exclusion of financial sector companies, namely, NACE 64, 65, and 66 (Fernández-Rodríguez et al., 2020). Only companies with yearly sales of greater than 1,000 EUR were left in the sample to avoid a distortion of the results by including small and potentially non-active firms. The primary database search resulted in obtaining the data for 1,585 companies. It should be mentioned that no data was available for Albania. Subsequently, firms with missing or incorrect data were excluded. Companies showing a loss were not excluded in order to analyse the loss carry-forward mechanism. The final sample consisted of 1,067 companies (6,402 firm-years), who's residence may be found in Tab. 1.

\section{Tab. 1 Data sample: residence}

\begin{tabular}{lcr}
\hline Country & Starting number of firm-years & Final number of firm-years \\
\hline Bulgaria & 744 & 504 \\
Croatia & 522 & 354 \\
Czech Republic & 48 & 36 \\
Estonia & 24 & 18 \\
Hungary & 54 & 48 \\
Latvia & 36 & 18 \\
Lithuania & 138 & 96 \\
Poland & 2,394 & 1,458 \\
Romania & 1,860 & 1,182 \\
Russia & 3,306 & 2,502 \\
Slovakia & 342 & 150 \\
Slovenia & 42 & 36 \\
TOTAL & $\mathbf{9 , 5 1 0}$ & $\mathbf{6 , 4 0 2}$ \\
\hline
\end{tabular}

Source: Authorial Computation. 
Purina, M: Human Freedom and Effective Corporate Income Tax Rates of CEE Listed Companies.

\subsection{The regression model}

According to Kubátová and Ř́hová (2009); Tsakumis et al. (2007); Lazar (2014); Němec and Dulák (2017); Fernández-Rodríguez et al. (2020), the regression model was defined as:

$$
\begin{aligned}
& E_{T R} R_{i t}=\beta_{0}+\beta_{1} \text { SIZE }_{i t}+\beta_{2} L E V_{i t}+\beta_{3} \text { CAPINT }_{i t}+\beta_{4} \text { INVINT }_{i t}+ \\
& \beta_{5} R_{0 A_{i t}}+\beta_{6} \mathrm{HFI}_{m t}+\beta_{7} S T R_{m t}+\beta_{8 m} \text { Dummy }_{\text {country }}+ \\
& \beta_{9 i} \text { Dummy }_{\text {sector }}+\beta_{10 t} \text { Dummy }_{\text {year }}+\varepsilon_{i t} \text {, }
\end{aligned}
$$

where $E T R$ is effective tax rate; $i$ denotes firms; $t$ represents years; $m$ is for countries; $\varepsilon_{i t}$ denotes a random error; explanatory variables are as follows:

- SIZE means a company's size as the natural logarithm of its total assets;

- $L E V$ is a firm's leverage measured as total debt divided by total invested capital;

- CAPINT stands for capital intensity calculated as total fixed assets to total assets ratio;

- INVINT means inventory intensity calculated as inventory to total assets ratio;

- ROA is return on assets: earnings before taxes to total assets ratio;

- $H F I$ is the Human Freedom Index;

- STR stands for statutory corporate income tax rate;

- Dummy country denotes which country a firm belongs to;

- Dummy sector shows which NACE sector a firm belongs to;

- Dummy year represents individual years.

To avoid possible distortions, three ETRs were included in the analysis according to Lazar (2013), where EBT means earnings before taxes and EAT means earnings after taxes:

$$
\begin{aligned}
& \text { ETR } 1=\frac{E B T-E A T}{E B T}, \\
& \text { ETR2 }=\frac{E B T-E A T}{\text { Turnover }}, \\
& \text { ETR3 }=\frac{E B T-E A T}{\text { Cash flow }} .
\end{aligned}
$$

ETR2 demonstrates how the turnover is distributed among different stakeholders. ETR3 shows the tax burden with respect to a company's cash flow (Lazar, 2013). 
European Financial and Accounting Journal, 2021, vol.16, no. 2, pp. 05-28.

Descriptive statistics for the companies included in the full sample may be found in Tab. 2.

Tab. 2 Descriptive statistics - the full sample

\begin{tabular}{lrrrrr}
\hline $\begin{array}{l}\text { Variable and } \\
\text { measure unit }\end{array}$ & Mean & Median & Minimum & Maximum & $\begin{array}{r}\text { Standard } \\
\text { deviation }\end{array}$ \\
\hline ETR1, \% & 13.280 & 15.523 & -6185.600 & 6861.0 & 170.570 \\
ETR2, \% & 2.549 & 0.609 & -284.410 & 9405.800 & 118.040 \\
ETR3, \% & 201.58 & 0.0 & $-892,250.0$ & 936,230 & $23,775.0$ \\
SIZE, th. EUR & $764,250.0$ & $33,810.0$ & 155.310 & $240,350,000.0$ & $7,740,700.0$ \\
LEV, \% & 86.287 & 94.767 & 0.889 & 100.0 & 18.781 \\
CAPINT, \% & 38.613 & 36.041 & 0.001 & 99.477 & 25.895 \\
INVINT, \% & 15.561 & 10.978 & 0.001 & 84.353 & 15.323 \\
ROA, \% & 4.069 & 3.184 & -82.786 & 86.316 & 10.355 \\
HFI, points & 7.328 & 7.780 & 6.110 & 8.540 & 0.841 \\
STR, \% & 18.116 & 19.000 & 9.000 & 23.000 & 2.907 \\
\hline SOUICE: Authorian
\end{tabular}

Source: Authorial computation.

Note 1: In the models, natural logarithms of SIZE, LEV, CAPINT, INVINT, HFI, and STR were taken to approach the normal distribution of variables and to smooth the extreme values. Remaining variables were harmonised using the $-\frac{1}{x}$ method. Subsequently, the tests listed in Appendix 1 proved that the model assumptions had been met.

Note 2: ETR2 is negative for companies that reported a negative income tax due to deferred taxes or a tax refund. This is especially the case for Russia, where these details may be reported together with the payable taxes. In the analysis, these companies are not excluded in order to avoid bias; nevertheless, running different regression models (including those without Russia) helps overcome this limitation.

While firm-specific factors vary greatly due to the individual characteristics of the companies included in the sample, country-specific factors demonstrate a lower-level standard deviation, with means that are approaching their medians. This fact proves that CEE countries are relatively close to each other with respect to the analysed parameters.

Taking into account the disproportionality of the samples with respect to the number of companies within each country, three different samples were analysed which resulted in nine models as follows:

- A full sample of 12 countries: ETR1 (model 1), ETR2 (model 2), ETR3 (model $3)$; 
- A sample of 11 countries excluding Russia: ETR1 (model 4), ETR2 (model 5), ETR3 (model 6). The reasons are: (i) almost one third of the entire sample is represented by Russian companies; (ii) Russia is not part of the EU, and its capital markets regulatory framework differs from that of the EU;

- A sample of four countries: Bulgaria, Croatia, Poland, and Romania: ETRI (model 7), ETR2 (model 8), ETR3 (model 9). These EU countries have the highest number of firms in the whole sample, so it was useful to see whether the same results would be obtained.

Tab. 10 and Tab. 11 display the means for all analysed countries. The highest average ETRl was recorded in the Czech Republic (21.669\%), while in Lithuania this indicator was negative $(-0.315 \%)$. This demonstrates why it is important to determine whether the results obtained from the entire sample are in line with the sample including only the largest countries. The ETR2 means remained relatively stable, increasing from 0.250 (Lithuania) to 5.075 (Russia). ETR3 means varied greatly because cash flow was used as the denominator.

A significant difference occurred between mean company sizes, where the leader was the Czech Republic (4,300,374,017 EUR), and the smallest is from Slovakia $(13,090,741$ EUR). Croatia demonstrated the lowest average leverage $(62.182 \%)$ and ROA (0.193\%). Inventory intensity varies from $3.507 \%$ (Estonia) to $23.386 \%$ (Latvia). Estonia achieved the best HFI level (8.419 points on average), and the worst result belonged to Russia (6.297 points). Russia also presented the lowest capital intensity $(30.175 \%)$ combined with the highest leverage (94.701\%). The highest STR ratio was demonstrated by Slovakia (23\% in 2013).

The correlation matrix for the analysed variables is presented in Tab. 12. To make sure that mutual correlations did not distort the results, the model was tested for multicollinearity (see Tab. 9): a variance inflation factor of greater than 10 means that there is a high level of multicollinearity, which is commonly interpreted as indicating potentially doubtful $p$-values; in the research, no variance inflation factor exceeded this limit.

\section{Results and Discussion}

The analysis of the models was conducted using panel data regression in gretl and MATLAB $\AA$ software packages according to Álvarez et al. (2017). This section summarises the main findings and describes them in light of existing literature.

After applying the F-test, Hausman test, and the Breusch-Pagan test (Bell et al., 2019), the fixed effects model was considered to be the most accurate.

The Feasible Generalised Least Squares estimator, as in Fernández-Rodríguez et al. (2020), was chosen using weighting based on per-unit error variances. The standard errors for the estimates were not clustered as in Van Pelt (2020), because the Wald 
European Financial and Accounting Journal, 2021, vol.16, no. 2, pp. 05-28. test did not prove heteroscedasticity in the data (see Tab. 6, Tab. 7, and Tab. 8). The results of the regression analysis may be found in Tab. 3, Tab. 4, and Tab. 5.

Tab. 3 Results of the regression analysis - full sample

\begin{tabular}{|c|c|c|c|c|c|c|}
\hline \multirow[t]{2}{*}{ Variable } & \multicolumn{2}{|c|}{ Model 1 (ETR1) } & \multicolumn{2}{|c|}{ Model 2 (ETR2) } & \multicolumn{2}{|c|}{ Model 3 (ETR3) } \\
\hline & Coefficient & $t(p$-value $)$ & Coefficient & $t(p$-value $)$ & Coefficient & $t(p$-value $)$ \\
\hline SIZE & 0.574 & $7.417 * * *$ & 0.089 & $21.77 * * *$ & 0.037 & $3.657 * * *$ \\
\hline$L E V$ & 2.981 & $7.351 * * *$ & -0.321 & $-10.31 * * *$ & -1.079 & $-3.221 * * *$ \\
\hline CAPINT & -0.729 & $-5.297 * * *$ & 0.031 & $3.643 * * *$ & 0.276 & $17.830 * * *$ \\
\hline INVINT & 1.069 & $11.47 * * *$ & -0.093 & $-15.42 * * *$ & 0.041 & $2.413^{* *}$ \\
\hline$R O A$ & 0.320 & $21.290 * * *$ & 0.550 & $128.6 * * *$ & 0.399 & $27.090 * * *$ \\
\hline$H F I$ & -50.193 & $-5.887 * * *$ & -1.604 & $-4.327 * * *$ & -7.392 & $-9.148^{* * *}$ \\
\hline STR & 16.990 & $3.891 * * *$ & 0.341 & $2.555^{* *}$ & 1.226 & $5.560 * * *$ \\
\hline Year Dummies & \multicolumn{2}{|c|}{ Included $* * *$} & \multicolumn{2}{|c|}{ Included $* * *$} & \multicolumn{2}{|c|}{ Included $* * *$} \\
\hline $\begin{array}{l}\text { Country } \\
\text { Dummies }\end{array}$ & \multicolumn{2}{|c|}{ Included $* * *$} & \multicolumn{2}{|c|}{ Included $* * *$} & \multicolumn{2}{|c|}{ Included $* * *$} \\
\hline NACE Dummies & \multicolumn{2}{|c|}{ Included $* * *$} & \multicolumn{2}{|c|}{ Included } & \multicolumn{2}{|c|}{ Included $* * *$} \\
\hline Observations & \multicolumn{2}{|c|}{6,402} & \multicolumn{2}{|c|}{6,402} & \multicolumn{2}{|c|}{6,402} \\
\hline Adjusted $\mathrm{R}^{2}$ & \multicolumn{2}{|c|}{$62.8 \%$} & \multicolumn{2}{|c|}{$97.0 \%$} & \multicolumn{2}{|c|}{$95.9 \%$} \\
\hline
\end{tabular}

Source: Authorial computation. Note: $* * * p<0.001, * * p<0.01, * p<0.05$.

Tab. 4 Results of the regression analysis - full sample without Russia

\begin{tabular}{|c|c|c|c|c|c|c|}
\hline \multirow[t]{2}{*}{ Variable } & \multicolumn{2}{|c|}{ Model 4 (ETR1) } & \multicolumn{2}{|c|}{ Model 5 (ETR2) } & \multicolumn{2}{|c|}{ Model 6 (ETR3) } \\
\hline & Coefficient & $t(p$-value $)$ & Coefficient & $t(p$-value $)$ & Coefficient & $t(p$-value $)$ \\
\hline SIZE & -0.030 & $-7.814 * * *$ & 0.045 & $7.995 * * *$ & 0.060 & $5.540 * * *$ \\
\hline$L E V$ & -0.301 & $-2.899 * * *$ & -1.495 & $-9.338 * * *$ & -2.072 & $-5.149 * * *$ \\
\hline CAPINT & -0.030 & $-4.011 * * *$ & 0.035 & $2.801 * * *$ & 0.251 & $9.594 * * *$ \\
\hline INVINT & 0.029 & $3.213 * * *$ & -0.204 & $-14.430 * * *$ & 0.194 & $7.691 * * *$ \\
\hline$R O A$ & -0.249 & $-40.960 * * *$ & 0.553 & $94.110 * * *$ & 0.402 & $27.26 * * *$ \\
\hline$H F I$ & -1.648 & $0.291 * * *$ & -1.937 & $-4.472 * * *$ & -8.161 & $-7.194 * * *$ \\
\hline STR & -1.774 & $-2.413 * * *$ & -2.014 & $-2.030 * *$ & -2.587 & $-2.137 * *$ \\
\hline Year Dummies & \multicolumn{2}{|c|}{ Included $* * *$} & \multicolumn{2}{|c|}{ Included $* * *$} & \multicolumn{2}{|c|}{ Included $* * *$} \\
\hline $\begin{array}{l}\text { Country } \\
\text { Dummies }\end{array}$ & \multicolumn{2}{|c|}{ Included $* * *$} & \multicolumn{2}{|c|}{ Included $* * *$} & \multicolumn{2}{|c|}{ Included $* * *$} \\
\hline
\end{tabular}


Purina, M: Human Freedom and Effective Corporate Income Tax Rates of CEE Listed Companies.

\begin{tabular}{lccc}
\hline Variable & Model 4 (ETR1) & Model 5 (ETR2) & Model 6 (ETR3) \\
& Coefficient & $\boldsymbol{t}(\boldsymbol{p}$-value) & Coefficient \\
\hline NACE Dummies & Included*** $^{*}$ & Included *** & Included*** \\
Observations & 3,900 & 3,900 & 3,900 \\
Adjusted $\mathrm{R}^{2}$ & $99.9 \%$ & $99.7 \%$ & $91.1 \%$ \\
\hline
\end{tabular}

Source: Authorial computation. Note: $* * * p<0.001, * * p<0.01, * p<0.05$.

Tab. 5 Results of the regression analysis - Bulgaria, Croatia, Poland, and Romania

\begin{tabular}{|c|c|c|c|c|c|c|}
\hline \multirow[t]{2}{*}{ Variable } & \multicolumn{2}{|c|}{ Model 7 (ETR1) } & \multicolumn{2}{|c|}{ Model 8 (ETR2) } & \multicolumn{2}{|c|}{ Model 9 (ETR3) } \\
\hline & Coefficient & $t(p$-value $)$ & Coefficient & $t(p$-value $)$ & Coefficient & $t(p$-value $)$ \\
\hline SIZE & -0.0330 & $-9.990 * * *$ & 0.033 & $6.973 * * *$ & 0.067 & $5.971 * * *$ \\
\hline$L E V$ & -0.0762 & $-3.110 * * *$ & -0.303 & $-9.455 * * *$ & -1.52 & $-3.768 * * *$ \\
\hline CAPINT & -0.033 & $-6.009 * * *$ & 0.050 & $4.627 * * *$ & 0.223 & $8.676^{* * *}$ \\
\hline$I N V I N T$ & -0.001 & $-2.190 * *$ & -0.178 & $-26.070 * * *$ & 0.081 & $3.299 * * *$ \\
\hline$R O A$ & -0.229 & $-40.28 * * *$ & 0.541 & $113.400 * * *$ & 0.397 & $25.900 * * *$ \\
\hline$H F I$ & -1.529 & $-6.157 * * *$ & -1.600 & $-3.924 * * *$ & -8.691 & $-8.947 * * *$ \\
\hline STR & 0.278 & $2.114 * *$ & 0.140 & 0.804 & 0.667 & 0.818 \\
\hline Year Dummies & \multicolumn{2}{|c|}{ Included $* * *$} & \multicolumn{2}{|c|}{ Included $* * *$} & \multicolumn{2}{|c|}{ Included $* * *$} \\
\hline $\begin{array}{l}\text { Country } \\
\text { Dummies }\end{array}$ & \multicolumn{2}{|c|}{ Included $* * *$} & \multicolumn{2}{|c|}{ Included $* * *$} & \multicolumn{2}{|c|}{ Included $* * *$} \\
\hline NACE Dummies & \multicolumn{2}{|c|}{ Included $* * *$} & \multicolumn{2}{|c|}{ Included } & \multicolumn{2}{|c|}{ Included $* * *$} \\
\hline Observations & \multicolumn{2}{|c|}{3,498} & \multicolumn{2}{|c|}{3,498} & \multicolumn{2}{|c|}{3,498} \\
\hline Adjusted $\mathrm{R}^{2}$ & \multicolumn{2}{|c|}{$98.4 \%$} & \multicolumn{2}{|c|}{$92.7 \%$} & \multicolumn{2}{|c|}{$92.9 \%$} \\
\hline
\end{tabular}

Source: Authorial computation.

Note: $* * * p<0.001, * * p<0.01, * p<0.05$.

Based on the conducted research, none of the hypotheses was rejected. The main variable of interest, HFI, was significant in all models and always had a negative coefficient. This significance is in line with the available coverage of studies (Frey and Torgler, 2007; Livingston, 2020; Torgler and Schneider, 2004; Williamson and Mathers, 2011). Although an individual's and a firm's decisionmaking strategies differ, culture includes all behaviours, beliefs, and values that strongly influence business performance (Kaplan et al., 2016). Broadening 
the previous research (Fernández-Rodríguez et al., 2020; Fonseca-Díaz et al., 2014) with a complex index that includes not only economic, but also personal freedoms, it may be concluded that the listed companies located in countries with a lower level of freedom have to pay higher corporate income tax. This finding also demonstrates that the individual cultural and institutional characteristics of each CEE country are more important for the ETR of its companies than the historical aspects of their recent experience of a mutual centrally planned economy. It must be pointed out that the study included CEE countries only; application of this approach to other regions may be the subject of an upcoming analysis.

Another country-specific variable, STR, has demonstrated positive coefficients as expected except for models 4, 5, and 6 (all models for the full sample excluding Russia). A specific reason may be found in further research; it may be assumed that it would be necessary to examine the tax policy and details in these states and to take into account possible international tax planning. This fact may be a reflection of tax competitiveness, which allows larger firms to efficiently and legally save on taxes as described in Sedmihradsky and Klazar (2002); Podviezko et al. (2019). STR was not significant in models 8 and 9, which may be explained by the construction of ETR2 and ETR3.

All firm-specific variables were found to be significant, which is consistent with previous research (Fatica et al., 2012; Fernández-Rodríguez et al., 2020; Purina, 2017; Sugeng and Badrus, 2020). A valuable finding is that signs of the coefficients for SIZE and ROA are different in model 1 compared with models 4, and 7. A special regression was run separately for Russia (though not shown here due to space constraints) to prove that the signs of SIZE and ROA are positive for Russian companies, which complies with political cost theory, whilst the rest of the analysed firms seem to act according to political power theory ${ }^{2}$. There is similar evidence for some other economies (e.g. Derashid and Zhang, 2003; Fernández-Rodríguez and Martínez-Arias, 2014).

Negative coefficients for leverage are also pursuant to the existing state of knowledge (Fernández-Rodríguez et al., 2020; Fonseca-Díaz et al., 2014; Němec and Dulák, 2017; Purina, 2017). Capital intensity and inventory intensity demonstrated ambivalent signs. I found negative coefficients for capital intensity in models 1,4 , and 7 , and for inventory intensity in models $2,5,7$, and 8 (i.e. mainly based on ETR2: increase in turnover may be caused by growing sales volume and, therefore, the volume of inventory). Negative coefficients for capital intensity and positive coefficients for inventory intensity are in line with FernándezRodríguez et al. (2020) and Sugeng and Badrus (2020). On the other hand, Němec

2 The separate regressions for Russia also demonstrated the significance of all analysed variables for all the ETRs. However, some coefficients (e.g. capital and material intensity and leverage) had ambivalent signs in different models, which may be a subject of future research. 
Purina, M: Human Freedom and Effective Corporate Income Tax Rates of CEE Listed Companies.

and Dulák (2017) and Lazar (2014) found negative coefficients for inventory intensity. This issue may be a field for future research.

Dummy variables for year, country, and NACE sector have been included in the model, though their coefficients are not shown to save space. All year dummies were highly significant $(p<0.001)$. In most cases (when marked properly in Tab. 3, Tab. 4, and Tab. 5) the NACE dummies were also significant. As for the country dummies, they were always significant. Therefore, a company's ETR is associated with, amongst other issues, its sector, the relevant year, and the country.

The next step of the analysis may include new groups of countries and longer periods as soon as the particular HFIs are available. It would also be possible to use alternative measures of culture level if the relevant data is appropriate, or to test individual parts of the HFI. The contemporary world economic crisis caused by the COVID-19 pandemic is a circumstance of insuperable force leading many businesses to bankruptcy. Changes in ETRs due to this fact may be a field for future research, as well as the inclusion of new countries if the relevant data is accessible. Information from regions with a different cultural background could prove to be revealing. A macroeconomic study of the problem may include the analysis of effective corporate income tax rates at country level as a corporate income tax to GDP ratio.

\section{Conclusions}

This paper aims to analyse how microeconomic ETRs are affected by firm-specific and country-specific factors, with emphasis on personal and economic freedoms covered by the Human Freedom Index. The entire sample includes 6,402 firm-years of data for CEE listed companies available from the BvD Amadeus database for the period 2013-2018. The analysis was conducted using nine models with different sample compositions (all CEE countries; CEE countries excluding Russia; only Bulgaria, Croatia, Poland, and Romania) and different ETR denominators (EBT; turnover; cash flow).

The factors affecting the ETR were divided into those that are firm-specific such as size, leverage, capital intensity, inventory intensity, and $R O A$, and those that are country-specific, namely the $H F I$ and $S T R$. The main variable of interest was the HFI as an approximation of personal and economic freedom within a particular society.

Based on the conducted research, none of the hypotheses was rejected. A significant influence for all variables included in the research was found. The HFI's coefficient for all CEE countries was negative, meaning that a higher level of personal and economic freedoms is associated with a smaller tax burden. No fundamental 
differences were registered for different sample compositions. This finding may be of interest regarding policy implications. Governments must be aware of the fact that growing levels of freedom may adversely affect tax morale; therefore, appropriate preliminary measures should be taken. As an example, digitalisation is worth mentioning, being a crucial tool for the simplification of tax procedures, which may increase the willingness to comply with prescribed requirements. Taking into account the cultural attitude to taxes is a crucial step for government policy in this area. A well-chosen motivation system may lead to a substantial increase in tax compliance. In some societies, still, only conditional tax cooperation is common, and if tax evasion becomes more widespread, the negative consequences may rapidly materialise because it would make it easier for taxpayers to justify their behaviour.

Any government would be hard pushed to change the deeply ingrained cultural and social norms, but sourcing taxpayers with a carefully designed set of rules and a certain level of economic freedom seems realistic. Even the particular choice of words may play an important role here: if stricter tax enforcement is explained by the necessity to cope with an increase in illegal tax activities, taxpayers are informed that this increase exists (although they may not be aware of it), and conditional cooperation comes into play. It is better to comment on enforcement from the perspective of keeping up a high level of compliance (Traxler, 2005).

It was also established that CEE countries excluding Russia share the same pattern of the inverse relationship between the ETR and STR. The size of a company and its $R O A$ were also negatively correlated with the ETRl. This may reflect (i) tax competitiveness in CEE countries being well known due to their low STR and lucrative conditions for large investors and (ii) the implication of political power theory.

Predicted results for leverage were obtained. A detailed analysis of capital and inventory intensity may be a subject of future research, taking into account the ambivalent opinions expressed within the existing literature.

I believe that this study represents an important advance in research on the ETR because it includes a new significant variable, the HFI, which has not been considered in this type of research before. The results of this paper may be applied by governments when proposing tax policy or by businesses when planning international activities. Cultural differences still play essential role within the globalised world, even though their impact may not be obvious at first glance. 
Purina, M: Human Freedom and Effective Corporate Income Tax Rates of CEE Listed Companies.

\section{References}

Allingham, M.G., Sandmo, A., 1972. Income Tax Evasion: A Theoretical Analysis. Journal of Public Economics 1, 3-4, 323-338.

Álvarez, I. C., Barbero, J., Zofío, J. L., 2017. A Panel Data Toolbox for MATLAB. Journal of Statistical Software 76, 6, 1-27. Available from: <paneldatatoolbox.com/>. [20 December 2016].

Audit-it, 2017. Nalogovoe planirovanie. Available from: <auditit.ru/terms/taxation/nalogovoe_planirovanie.html>. [14 July 2021].

Becker, G., 1983. A Theory of Competition Among Pressure Groups for Political Influence. Quarterly Journal of Economics 98, 3, 371-400.

Bell, A., Fairbrother, M., Jones, K., 2019. Fixed and Random Effects Models: Making an Informed Choice. Quality \& Quantity 53, 2, 1051-1074.

Berenson, M., 2018. Creating Post-communist Tax Regimes and Measuring Tax Compliance. In Taxes and Trust: From Coercion to Compliance in Poland, Russia and Ukraine, 96-136. Cambridge: Cambridge University Press.

Cummings, R. G., Martinez-Vazquez, J., McKee, M., Torgler, B., 2004. Effects of Culture on Tax Compliance: A Cross Check of Experimental and Survey Evidence. Working paper No. 2004-13, Centre for Research in Economics, Management and the Arts.

DeBacker, J., Bradley, T. H., Tran, A., 2015. Importing Corruption Culture from Overseas: Evidence from Corporate Tax Evasion in the United States. Journal of Financial Economics 117, 1, 122-138.

Derashid, C., Zhang, H., 2003. Effective tax rates and the "industrial policy" hypothesis: evidence from Malaysia. Journal of International Accounting, Auditing and Taxation 12, 45-62.

Fatica, S., Hemmelgarn, T., Nicodème, G., 2012. The Debt-Equity Tax Bias: consequences and solutions. Taxation Paper No. 33, European Commission.

Fernández-Rodríguez, E., García-Fernández, R., Martínez-Arias, A. 2020. Business and Institutional Determinants of ETR in Emerging Economies. Economic Modelling. In press.

Fernández-Rodríguez, E., Martínez-Arias, A., 2014. Determinants of the effective tax rate in the BRIC countries. Emerging Markets Finance Trade 50, 214-228.

Fonseca-Díaz, A.R., Fernández-Rodríguez, E., Martínez-Arias, A., 2014. Geographic and Institutional Determinants of International Tax Burden for Corporate Income Tax. Journal of Global Competition Governability 8, 16-32.

Frey, B. S., Torgler, B., 2007. Tax Morale and Conditional Cooperation. Journal of Comparative Economics 35(1), 136-159. 
Gulev, R. E., Lierse, H., 2011. Exploring the Connection between Culture and Taxation: How Trust and Confidence Shape Tax Regimes within Europe. In: MIC 2011: Managing Sustainability? [Conference Proceedings]. Portorož: University of Primorska, Faculty of Management Koper. Available from: <ideas.repec.org/h/mgt/micp11/1065-1083.html>. [20 July 2019].

Gupta, S., Newberry, K. 1997. Determinants of the Variability in Corporate Effective Tax Rates: Evidence from Longitudinal Data. Journal of Accounting and Public Policy 16, 1, 1-34. DOI: 10.1016/S0278-4254(96)00055-5.

Hofstede, G, J., 2015. Dimension Data Matrix. Available from: <geerthofstede.com/research-and-vsm/dimension-data-matrix/>. $\quad\left[\begin{array}{ll}10 & \text { January }\end{array}\right.$ 2020].

Inglehart, R., Haerpfer, C., Moreno, A., Welzel, C., Kizilova, K., Diez-Medrano, J., Lagos, M., Norris, P., Ponarin, E., Puranen, B. et al. (eds.), 2014. World Values Survey: Round Six - Country-Pooled Datafile Version, Madrid: JD Systems Institute. Available from: <worldvaluessurvey.org/WVSDocument ationWV6.jsp>. [15 January 2020].

Kaplan, M. et al., 2016. Shape Culture. Drive Strategy. Deloitte Insights. Available from: $\quad<$ https://www2.deloitte.com/us/en/insights/focus/human-capitaltrends/2016/impact-of-culture-on-business-strategy.html>. [17 April 2020].

Kaufmann, D., Kraay, A., Mastruzzi, M., 2011. The Worldwide Governance Indicators: Methodology and Analytical Issues. Hague Journal on the Rule of Law 3(2), 220-246.

Kountouris, Y., Remoundou, K., 2013. Is There a Cultural Component in Tax Morale? Evidence from Immigrants in Europe. Journal of Economic Behavior \& Organization 96, 104-119.

KPMG, 2021. Corporate Tax Rates Table. Available from: $<$ home.kpmg/xx/en/home/services/tax/tax-tools-and-resources/tax-ratesonline/corporate-tax-rates-table.html> . [13 July 2021].

Kubátová, K., ̌̌íhová, L., 2009. Regresní analýza faktorů ovlivňujících výnosy korporativní daně v zemích OECD. Politická ekonomie 57, 4, 451-470..

Lazar, S., 2013. Effective Corporate Taxation in Romania. Evidence from the Bucharest Stock Exchange. Eastern European Economics 51, 4, 50-83..

Lazar S., 2014. Determinants of the Variability of Corporate Effective Tax Rates. Evidence from the Romanian Listed Companies. Emerging Markets, Finance and Trade 50 (4), 113-131..

Livingston, M., 2020. Tax and Culture: Convergence, Divergence, and the Future of Tax Law. Cambridge University Press, Cambridge. ISBN: 978-1-107-13684-7.

Luttmer, E. F. P., Singhal, M., 2014. Tax Morale. The Journal of Economic Perspectives 28, 4, 149-168. 
Purina, M: Human Freedom and Effective Corporate Income Tax Rates of CEE Listed Companies.

Miller, T., Kim, A. B., 2016. 2016 Index of Economic Freedom. Wall Street Journal, New York. Available from: <heritage.org/index/pdf/2016/book/index_2016.pdf>. [20 December 2020].

Molina-Morales, A., Amate-Fortes, I., Guarnido-Rueda, A., 2011. Economic and Institutional Determinants in Fiscal Pressure: an Application to the European Case. Journal of Economic Issues 45, 573-591.

Němec, D., Dulák, S., 2017. Modelling effective corporate tax rate in the Czech Republic. In: Pavel Pražák, 35th International Conference Mathematical Methods in Economics MME 2017 Conference Proceedings, Hradec Králové: Faculty of Informatics and Management, University of Hradec Králové, 2017, 511-516, ISBN 978-80-7435-678-0. Available from: <fim2.uhk.cz/mme/index.php?page= conferenceproceedings $>$. [20 February 2020].

Nicodème, G., 2007. Comparing effective corporate tax rates. Frontiers in Finance and Economics 4, 2, 102-131.

Podviezko, A., Parfenova, L., Pugachev, A., 2019. Tax Competitiveness of the New EU Member States. Journal of Risk and Financial Management 12, 34.

Posner, E., 2000. Law and Social Norms: The Case of Tax Compliance. Virginia Law Review 86(8), 1781-1819.

Purina, M., 2017. Factors Affecting Effective Corporate Income Tax Rate of the Czech and Russian "Blue Chips" in 2012 - 2015. European Financial and Accounting Journal 12, 1, 51-69.

Sedmihradsky, M., Klazar, S., 2002. Tax Competition for FDI in Central-European Countries, CESifo Working Paper No. 647, Center for Economic Studies and ifo Institute (CESifo), Munich. Available from: <econstor.eu/bitstream/10419/76066/1/cesifo_wp647.pdf>. [31 October 2020].

Sugeng, E. P., Zaman, B., 2020. Does capital intensity, inventory intensity, firm size, firm risk, and political connections affect tax aggressiveness? JEMA: Jurnal Ilmiah Bidang Akuntansi dan Manajemen 17, 1, 2020, 78-87.

Torgler, B., 2007. Tax Compliance and Tax Morale: A Theoretical and Empirical Analysis. Edward Elgar Publishing, Cheltenham. ISBN: 9781845427207.

Torgler, B., Schneider, F., 2004. Does Culture Influence Tax Morale? Evidence from Different European Countries. Working Paper No. 2004-17, Centre for Research in Economics, Management and the Arts. Available from: <researchgate.net/publication/4762280_Does_Culture_Influence_Tax_Mora le_Evidence_from_Different_European_Countries>. [28 February 2020].

The Heritage Foundation, 2020. The Index of Economic Freedom. Available from: $<$ heritage.org/index/about>. [31 October 2020]. 
Traxler, Ch., 2005. Tax Evasion, Social Norms and Conditional Cooperation. Available from: <d-nb.info/978943503/34>. [15 July 2021].

Trüdinger, E.-V., Hildebrandt, A., 2013. Causes and Contexts of Tax Morale: Rational Considerations, Community Orientations, and Communist Rule. International Political Science Review 34, 2, 191-209. Available from: $<$ jstor.com/stable/23353494>. [27 June 2020].

Tsakumis, G. T., Curatola, A. P., Porcano, T. M., 2007. The Relation between National Cultural Dimensions and Tax Evasion. Journal of International Accounting, Auditing and Taxation 16, 131-147.

Van Pelt, V. F. J., 2020. When and how to cluster standard errors in experimental data? Accounting Experiments. Available from: <accountingexperiments.com/post/clustering/>. [14 July 2021].

Vásquez, I., Porcnik, T., 2017-2020. The Human Freedom Index. Available from: <cato.org/human-freedom-index>. [17 May 2020].

Vásquez, I., McMahon, F., 2021. The Human Freedom Index. Available from: <cato.org/human-freedom-index>. [17 April 2021].

Williamson, C., Mathers, R. 2011. Economic Freedom, Culture, and Growth. Public Choice 148, 313-335.

Zimmerman, J. 1983. Taxes and Firm Size. Journal of Accounting and Economics $5,1,119-149$. 
Purina, M: Human Freedom and Effective Corporate Income Tax Rates of CEE Listed Companies.

\section{Appendix 1: Regression models estimation}

Tab. 6 Regression models assumptions estimation $(\alpha=0.001)$ - full sample

\begin{tabular}{lccccc}
\hline \multicolumn{1}{c}{$\begin{array}{c}\text { Assumption } \\
\text { (null hypothesis) }\end{array}$} & Test & Conclusion & \multicolumn{3}{c}{$\boldsymbol{p}$-values for models } \\
\cline { 3 - 6 } & & $\mathbf{1}$ & $\mathbf{2}$ & $\mathbf{3}$ \\
\hline $\begin{array}{l}\text { No autocorrelation in } \\
\text { the residuals }\end{array}$ & $\begin{array}{c}\text { Durbin-Watson } \\
\text { statistics }\end{array}$ & $\begin{array}{c}\text { The null hypothesis cannot be } \\
\text { rejected }\end{array}$ & 1.609 & 1.596 & 1.326 \\
Heteroscedasticity & Wald test & $\begin{array}{c}\text { Strong evidence against the null } \\
\text { hypothesis }\end{array}$ & 0.000 & 0.000 & 0.000 \\
$\begin{array}{l}\text { No cross-sectional } \\
\text { dependence }\end{array}$ & Pesaran CD test & $\begin{array}{c}\text { The null hypothesis cannot be } \\
\text { rejected (except for Model 2) }\end{array}$ & 0.473 & 0.000 & 0.369 \\
\hline
\end{tabular}

Source: Authorial Computation.

Tab. 7 Regression models assumptions estimation $(\alpha=0.001)-$ sample without Russia

\begin{tabular}{lccccc}
\hline \multicolumn{1}{c}{$\begin{array}{c}\text { Assumption } \\
\text { (null hypothesis) }\end{array}$} & Test & Conclusion & \multicolumn{2}{c}{$\boldsymbol{p}$-values for models } \\
\cline { 3 - 6 } & & $\mathbf{4}$ & $\mathbf{5}$ & $\mathbf{6}$ \\
\hline $\begin{array}{l}\text { No autocorrelation in } \\
\text { the residuals }\end{array}$ & $\begin{array}{c}\text { Durbin-Watson } \\
\text { statistics }\end{array}$ & $\begin{array}{c}\text { The null hypothesis cannot be } \\
\text { rejected }\end{array}$ & 1.629 & 1.615 & 1.309 \\
Heteroscedasticity & Wald test & $\begin{array}{c}\text { Strong evidence against the null } \\
\text { hypothesis }\end{array}$ & 0.000 & 0.000 & 0.000 \\
$\begin{array}{l}\text { No cross-sectional } \\
\text { dependence }\end{array}$ & Pesaran CD test & $\begin{array}{c}\text { The null hypothesis cannot be } \\
\text { rejected }\end{array}$ & 0.032 & 0.015 & 0.727 \\
\hline
\end{tabular}

Source: Authorial Computation.

Tab. 8 Regression models assumptions estimation $(\alpha=0.001)$ - Bulgaria, Croatia, Poland, and Romania

\begin{tabular}{|c|c|c|c|c|c|}
\hline \multirow{2}{*}{$\begin{array}{c}\text { Assumption } \\
\text { (null hypothesis) }\end{array}$} & \multirow[t]{2}{*}{ Test } & \multirow[t]{2}{*}{ Conclusion } & \multicolumn{3}{|c|}{$p$-values for models } \\
\hline & & & 7 & 8 & 9 \\
\hline $\begin{array}{l}\text { No autocorrelation in } \\
\text { the residuals }\end{array}$ & $\begin{array}{l}\text { Durbin-Watson } \\
\text { statistics }\end{array}$ & $\begin{array}{l}\text { The null hypothesis cannot be } \\
\text { rejected }\end{array}$ & 1.645 & 1.632 & 1.307 \\
\hline Heteroscedasticity & Wald test & $\begin{array}{l}\text { Strong evidence against the null } \\
\text { hypothesis }\end{array}$ & 0.000 & 0.000 & 0.000 \\
\hline $\begin{array}{l}\text { No cross-sectional } \\
\text { dependence }\end{array}$ & Pesaran CD test & $\begin{array}{l}\text { The null hypothesis cannot be } \\
\text { rejected (except for Models } 7 \\
\text { and 8) }\end{array}$ & 0.000 & 0.000 & 0.888 \\
\hline
\end{tabular}

Source: Authorial Computation. 
Tab. 9 Multicollinearity detection using variance inflation factors (VIF)

\begin{tabular}{lrr}
\hline Variable & VIF & Conclusion \\
\hline SIZE & 1.182 & No multicollinearity \\
LEV & 1.160 & No multicollinearity \\
CAPINT & 1.099 & No multicollinearity \\
INVINT & 1.276 & No multicollinearity \\
ROA & 1.107 & No multicollinearity \\
HFI & 1.518 & No multicollinearity \\
STR & 2.088 & No multicollinearity \\
\hline
\end{tabular}

Source: Authorial Computation.

Appendix 2: Descriptive statistics and Pearson correlations

Tab. 10 Means by countries, part 1

\begin{tabular}{lrrrrr}
\hline Country & $\boldsymbol{E T R}$, \% & $\boldsymbol{E T R 2 , \%}$ & $\boldsymbol{E T R 3 , \%}$ & SIZE, th. EUR & $\boldsymbol{L E V}, \boldsymbol{\%}$ \\
\hline Bulgaria & 6.705 & 0.693 & 246.981 & $36,014.576$ & 80.503 \\
Croatia & 2.473 & 0.631 & 63.840 & $138,878.357$ & 62.182 \\
Czech Republic & 21.669 & 3.888 & 90.604 & $4,300,374.017$ & 83.291 \\
Estonia & 11.906 & 3.295 & -28.700 & $409,104.994$ & 78.453 \\
Hungary & 16.399 & 1.542 & -35.540 & $2,410,185.755$ & 84.002 \\
Latvia & 18.343 & 0.357 & 274.954 & $39,152.699$ & 63.596 \\
Lithuania & -0.315 & 0.250 & 574.793 & $167,889.799$ & 71.340 \\
Poland & 20.342 & 1.041 & -51.338 & $456,999.430$ & 90.743 \\
Romania & 12.651 & 0.941 & -79.544 & $99,398.649$ & 77.594 \\
Russia & 1.028 & 5.075 & -785.467 & $1,489,043.179$ & 94.701 \\
Slovakia & 14.315 & 0.693 & -128.981 & $13,090.741$ & 62.820 \\
Slovenia & 3.135 & 0.308 & -36.401 & $513,657.441$ & 83.040 \\
\hline
\end{tabular}

Source: Authorial Computation. 
Purina, M: Human Freedom and Effective Corporate Income Tax Rates of CEE Listed Companies.

Tab. 11 Means by countries, part 2

\begin{tabular}{lccccc}
\hline Country & CAPINT, \% & INVINT, \% & ROA, \% & HFI, points & STR, \% \\
\hline Bulgaria & 45.280 & 14.242 & 1.603 & 7.832 & 10.000 \\
Croatia & 49.611 & 10.752 & 0.193 & 7.783 & 19.333 \\
Czech Republic & 45.278 & 10.674 & 9.743 & 8.287 & 19.000 \\
Estonia & 53.208 & 3.507 & 10.609 & 8.419 & 20.333 \\
Hungary & 46.366 & 8.576 & 7.541 & 7.760 & 15.667 \\
Latvia & 46.756 & 23.386 & 2.785 & 8.239 & 15.833 \\
Lithuania & 47.531 & 22.117 & 4.297 & 8.250 & 15.000 \\
Poland & 30.607 & 16.918 & 4.014 & 7.977 & 19.000 \\
Romania & 56.545 & 13.936 & 0.999 & 8.100 & 16.000 \\
Russia & 30.175 & 16.544 & 6.648 & 6.297 & 20.000 \\
Slovakia & 53.481 & 15.554 & 0.287 & 8.020 & 21.833 \\
Slovenia & 45.403 & 10.800 & 2.786 & 7.945 & 17.667 \\
\hline Source: Auth & & & &
\end{tabular}

Source: Authorial Computation.

\section{Tab. 12 Pearson correlation matrix}

\begin{tabular}{|c|c|c|c|c|c|c|c|c|c|c|}
\hline & ETR1 & ETR2 & ETR3 & SIZE & $L E V$ & CAPINT & INVINT & $R O A$ & HFI & STR \\
\hline ETRI & 1 & - & - & -0.006 & -0.007 & -0.014 & 0.021 & $\begin{array}{r}-0.290 \\
* * *\end{array}$ & -0.024 & $\begin{array}{r}0.204 \\
\text { *** }\end{array}$ \\
\hline ETR2 & & 1 & - & $\begin{array}{r}0.201 \\
* * *\end{array}$ & 0.003 & -0.003 & $\begin{array}{r}-0.216 \\
* * *\end{array}$ & $\begin{array}{r}0.541 \\
* * *\end{array}$ & $\begin{array}{r}-0.184 \\
* * *\end{array}$ & $\begin{array}{r}0.184 \\
* * *\end{array}$ \\
\hline ETR3 & & & 1 & $\begin{array}{r}0.102 \\
* * *\end{array}$ & $\begin{array}{r}0.048 \\
*\end{array}$ & $\begin{array}{r}0.083 \\
* * *\end{array}$ & 0.002 & $\begin{array}{r}0.290 \\
* * *\end{array}$ & $\begin{array}{r}-0.177 \\
* * *\end{array}$ & $\begin{array}{r}0.129 \\
* * *\end{array}$ \\
\hline SIZE & & & & 1 & $\begin{array}{r}0.146 \\
* * *\end{array}$ & $\begin{array}{r}-0.065 \\
* *\end{array}$ & $\begin{array}{r}-0.147 \\
* * *\end{array}$ & $\begin{array}{r}0.130 \\
* * *\end{array}$ & $\begin{array}{r}-0.260 \\
* * *\end{array}$ & $\begin{array}{r}0.231 \\
* * *\end{array}$ \\
\hline$L E V$ & & & & & 1 & $\begin{array}{r}-0.147 \\
* * *\end{array}$ & $\begin{array}{r}0.150 \\
* * *\end{array}$ & $\begin{array}{r}0.171 \\
* * *\end{array}$ & $\begin{array}{r}-0.267 \\
* * *\end{array}$ & $\begin{array}{r}0.190 \\
* * *\end{array}$ \\
\hline CAPINT & & & & & & 1 & -0.018 & $\begin{array}{r}-0.093 \\
* * *\end{array}$ & $\begin{array}{r}0.170 \\
* * *\end{array}$ & $\begin{array}{r}-0.146 \\
* * * *\end{array}$ \\
\hline INVINT & & & & & & & 1 & 0.017 & -0.026 & 0.018 \\
\hline$R O A$ & & & & & & & & 1 & $\begin{array}{r}-0.223 \\
* * *\end{array}$ & $\begin{array}{r}0.183 \\
* * *\end{array}$ \\
\hline$H F I$ & & & & & & & & & 1 & $\begin{array}{r}-0.427 \\
* * *\end{array}$ \\
\hline STR & & & & & & & & & & 1 \\
\hline
\end{tabular}

Note: $* * * \mathrm{p}<0.001, * * \mathrm{p}<0.01, * \mathrm{p}<0.05$.

Source: Authorial Computation. 